\title{
Enzymatic characterization of $O$-GlcNAcase isoforms using a fluorogenic GlcNAc substrate
}

\author{
Eun Ju Kim, ${ }^{\mathrm{a}, *}$ Dae Ook Kang, ${ }^{\mathrm{b}}$ Dona C. Love ${ }^{\mathrm{a}}$ and John A. Hanover ${ }^{\mathrm{a}}$ \\ ${ }^{a}$ Laboratory of Cell Biochemistry and Biology, NIDDK, National Institutes of Health, MD 20892, USA \\ ${ }^{\mathrm{b}}$ Department of Health Science and Biochemistry, College of Natural Sciences, Changwon National University, \\ 9 Sarim-Dong, Changwon, Kyungnam 641-773, South Korea
}

Received 28 October 2005; received in revised form 17 February 2006; accepted 2 March 2006

Available online 11 April 2006

\begin{abstract}
A highly sensitive fluorogenic hexosaminidase substrate, fluorescein $\operatorname{di}(N$-acetyl- $\beta$-D-glucosaminide) (FDGlcNAc), was prepared essentially as described previously [Chem. Pharm. Bull. 1993, 41, 314] with some modifications. The fluorescent analog is a substrate for a number of hexosaminidases but here we have focused on the cytoplasmic $O$-GlcNAcase isoforms. Kinetic analysis using purified $O$-GlcNAcase and its splice variant ( $v$-O-GlcNAcase) expressed in Escherichia coli suggests that FDGlcNAc is a much more efficient substrate $\left(K_{\mathrm{m}}=84.9 \mu \mathrm{M}\right)$ than the conventional substrate, para-nitrophenyl 2-acetamido-2-deoxy- $\beta$-D-glucopyranoside $\left(p N P-\beta-G l c N A c, K_{\mathrm{m}}=1.1 \mathrm{mM}\right.$ ) and a previously developed fluorogenic substrate, 4-methylumbelliferyl 2-acetamido2-deoxy- $\beta$-D-glucopyranoside [MUGlcNAc, $K_{\mathrm{m}}=0.43 \mathrm{mM} ; J$. Biol. Chem. 2005, 280, 25313] for $O$-GlcNAcase. The variant $O$ GlcNAcase, a protein lacking the C-terminal third of the full-length $O$-GlcNAcase, exhibited a $K_{\mathrm{m}}$ of $2.1 \mathrm{mM}$ with respect to FDGlcNAc. This shorter isoform was not previously thought to exhibit $O$-GlcNAcase activity based on in vitro studies with $p$ NP- $\beta$-GlcNAc. However, both $O$-GlcNAcase isoforms reduced $O$-GlcNAc protein levels extracted from HeLa and HT-29 cells in vitro, indicating that the splice variant is a bona fide $O$-GlcNAcase. Fluorescein di- $N$-acetyl- $\beta$-D-galactosaminide (FDGalNAc) is not cleaved by these enzymes, consistent with previous findings that the $O$-GlcNAcase has substrate specificity toward $O$-GlcNAc but not $O$-GalNAc. The enzymatic activity of the shorter isoform of $O$-GlcNAcase was first detected by using highly sensitive fluorogenic FDGlcNAc substrate. The finding that $O$-GlcNAcase exists as two distinct isoforms has a number of important implications for the role of $O$-GlcNAcase in hexosamine signaling.

Published by Elsevier Ltd.
\end{abstract}

Keywords: $O$-GlcNAc; OGT; $O$-GlcNAcase; $v$-O-GlcNAcase; FDGlcNAc; MUGlcNAc; $p$ NP- $\beta$-GlcNAc

Abbreviations: FDGlcNAc, fluorescein di- $N$-acetyl- $\beta$-D-glucosaminide; $O$-GlcNAcase, a full-length form of peptide $O$-GlcNAc- $\beta$ - $N$-acetylglucosaminidase; $v$-O-GlcNAcase, a shorter isoform of peptide $O$-GlcNAc- $\beta$ - $N$-acetylglucosaminidase; PNP-, para-nitrophenyl-; $O$ GlcNAc, $O$-linked $\beta$ - $N$-acetylglucosamine; FDGalNAc, fluorescein di- $N$-acetyl- $\beta$-D-galactosaminide; $O$-GalNAc, $O$-linked $\beta$ - $N$-acetylgalactosamine; OGT, protein uridine diphospho- $N$-acetylglucosamine: polypeptide $\beta$ - $N$-acetylglucosaminyl transferase; MUGlcNAc, 4-methylumbelliferyl 2-acetamido-2-deoxy- $\beta$-D-glucopyranoside; UDP, uridine diphosphate; DMSO, dimethyl sulfoxide; NMR, nuclear magnetic resonance; TLC, thin-layer chromatography; FAB MS, fast atom bombardment mass spectroscopy; LC-ESIMS, combined liquid chromatography and electrospray ionization spectroscopy; HPLC, high performance liquid chromatography; PBS, phosphate-buffered saline; DMEM, Dulbecco's modified eagle medium; PUGNAC, $O$-(2-acetamido-2-deoxy-D-glucopyranosylidene)-amino- $N$-phenylcarbamate.

* Corresponding author. Tel.: +1 301496 9405; fax: +1 301496 9431; e-mail: eunjuk@intra.niddk.nih.gov

\section{Introduction}

Many nuclear and cytoplasmic proteins such as transcription factors, ${ }^{1-3}$ cytoskeletal proteins, ${ }^{4,5}$ oncogenes, ${ }^{6}$ kinases, ${ }^{7}$ phosphatases, ${ }^{8}$ and chaperones, ${ }^{9-11}$ are known to be post-translationally modified with $O$-linked $\beta-N$ acetylglucosamine ( $O$-GlcNAc). The $O$-GlcNAc modification is ubiquitous in all higher eukaryotes that have been examined. In contrast to classical glycosylation, which occurs on membrane and secretory proteins with either N- or O-linkage in a more complex fashion, this modification is added to intracellular proteins through a $\beta$-O-linkage. The $O$-GlcNAc modification may act in a manner analogous to protein phosphorylation in that it is modulated by various extracellular stimuli and 
growth conditions ${ }^{12}$ and the turnover rate of the glycan is much faster than that of the polypeptide backbone. This implies that $O$-GlcNAc is dynamically added to and removed from proteins. ${ }^{13-15}$ Analogous to kinases and phosphatases, two enzymes are involved in the regulated cycling of $O$-GlcNAc. Sites modified by $O$ GlcNAc are often the same or adjacent to those of phosphorylation suggesting a competitive role for $O$-GlcNAc and phosphorylation in regulating protein function. ${ }^{16-18}$ Recent evidence suggests that deregulation of cellular $O$-GlcNAc levels might play a role in type II diabetes, ${ }^{19}$ cancer, ${ }^{20}$ and neurological disorders. ${ }^{21}$ For example, elevation of $O$-GlcNAc levels by altering one of the enzymes of $O$-GlcNAc metabolism can give rise to insulin resistance in transgenic mice ${ }^{19}$ and in tissue culture. ${ }^{22}$

The enzymes responsible for the cycle of $O$-GlcNAc addition and removal are the $O$-GlcNAc transferase (OGT, EC 2.4.1.94) and the $O$-GlcNAc specific $\beta-N$ acetylglucosaminidase known as $O$-GlcNAcase (EC 3.2.1.52). Both enzymes have been purified, cloned, and characterized. ${ }^{7,23-29}$ Recently, the crystal structure of the multiple tetratricopeptide repeats (TPR) domain of OGT has been solved and the TPR domain was shown to play a role in dimerization of OGT itself. ${ }^{30}$ Compared to OGT, very little is known about the $O$ GlcNAcase or its splice variant. Unlike acidic hexosaminidases in lysosomes, $O$-GlcNAcase has a neutral $\mathrm{pH}$ optimum, nucleocytoplasmic distribution, and substrate specificity toward GlcNAc and not $N$-acetylgalactosamine (GalNAc) ${ }^{29}$ Because of these distinct characteristics, $O$-GlcNAcase is most likely the same enzyme as hexosaminidase C..$^{31,32}$ The primary sequence of $O$ GlcNAcase was originally identified as meningioma expressed antigen 5 (MGEA 5), an autoantigen in meningiomas. ${ }^{33}$ Interestingly, the $O$-GlcNAcase gene maps to chromosome 10q24 and this locus has been implicated in Alzheimer's disease. ${ }^{33}$ Full-length $O$-GlcNAcase is a 916-amino acid protein having an acidic isoelectric point with a predicted molecular weight of $103 \mathrm{kDa}^{27,33}$ The $\mathrm{N}$-terminal and the $\mathrm{C}$-terminal region of $O$-GlcNAcase has homology to hyaluronidases ${ }^{33,34}$ and acetyltransferases, ${ }^{35}$ respectively. The C-terminal of $O$-GlcNAcase has recently been shown to have histone acetyltransferase (HAT) activity. ${ }^{36}$ A splice variant of $O$-GlcNAcase designated as MGEA 5 s was also identified. ${ }^{33}$ This isoform is a 677 -amino acid protein that lacks C-terminal third of the full-length $O$-GlcNAcase (the HAT domain). ${ }^{33,34}$ The crystal structure of either $O$-GlcNAcase or $v$-O-GlcNAcase has not yet been solved. Recently, Vocadlo and co-workers proposed that $O$-GlcNAcase utilizes a substrate-assisted mechanism of action. ${ }^{37}$ In that mechanism, 2-acetamido group of the substrate is involved in catalytic hydrolysis via formation and breakdown of a bicyclic oxazoline or oxazolinium ion intermediate leading to the retention of the stereochemistry at anomeric center of the sub- strate. However, neither residues acting as the catalytic nucleophile or the base, nor the region responsible for either the $O$-GlcNAcase activity or the substrate binding site has been clearly established. Instead, two opposite hypotheses have been proposed. ${ }^{35,38-40}$ The N-terminal 'hyaluronidase' domain has been proposed to be the catalytic site for $O$-GlcNAc removal based on the fact that both isoforms of $O$-GlcNAcase have the same amino terminus and this $\mathrm{N}$-terminal region has limited homology with other glycosidases. ${ }^{38} O$-GlcNAcase is categorized into the family 84 of glycoside hydrolases $(\mathrm{GH})$ as defined by the carbohydrate-active enzymes (CAZy) database. In support of the proposal that the $\mathrm{N}$-terminal region is responsible for the catalytic $O$-GlcNAcase activity, Rigden et al. ${ }^{39}$ demonstrated that the common conserved N-terminus region in the glycoside hydrolase (GH) family 84 is likely to conform to the catalytic triosephosphate isomerase (TIM) barrel fold. Whereas, the opposite proposal that the $O$-GlcNAcase catalytic activity resides in the $\mathrm{C}$-terminal acetyltransferase domain was based on the observation ${ }^{40}$ that $O$-GlcNAcase enzymatic activity has never been detected in the splice variant of $O$-GlcNAcase that lacks the putative histone acetyltransferase domain. ${ }^{36}$ To date, the functional role of the splice variant is still unclear.

The standard in vitro assay for measuring $O$-GlcNAcase uses $p$ NP- $\beta$-GlcNAc as a substrate. ${ }^{29}$ Enzyme activity is monitored spectrophotometrically by measuring the absorbance at $400 \mathrm{~nm}$ of a $p$-nitrophenolate ion that is enzymatically released from $p$ NP- $\beta$-GlcNAc. ${ }^{29,41}$ However, this assay is relatively insensitive because the substrate undergoes only a modest change in absorbance upon cleavage.

To facilitate the study of $O$-GlcNAcase isoforms, a highly sensitive method is necessary. Because fluorescence is highly sensitive, a great number of fluorogenic substrates have been widely used in a variety of biological areas. ${ }^{37,42-46}$ To date, a number of hexosaminidases have been examined by using fluorescent analogues and the sensitivities and usefulness of fluorogenic assays have been demonstrated. ${ }^{37,42-46}$ For example, fluorescein di- $\beta$-D-galactoside (FDG) has been used to measure the degree of transfection of the $\beta$-galactosidase reporter gene. ${ }^{43}$ The sensitivity of this fluorometric assay was found to be 50 -fold higher than that of the spectrophotometric assay of $\beta$-galactosidase with $o$-nitrophenyl- $\beta$-D-galactopyranoside. ${ }^{44}$ Vocadlo and co-workers used a series of 4-methylumbelliferyl 2- $N$-acetyl-2-deoxy$\beta$-D-gluocopyranosides (MUGlcNAc) as fluorogenic substrates for $O$-GlcNAcase in elucidating the catalytic mechanism of $O$-GlcNAcase. ${ }^{37}$ The fluorescent moiety in MUGlcNAc is 4-methylumbelliferone. However, it has been reported that the sensitivity of the assay using FDG is more than 10-fold higher than that of the assay with 4-methylumbelliferyl- $\beta$-D-galactoside. ${ }^{45}$ In other words, the sensitivity of the assay was higher when fluo- 


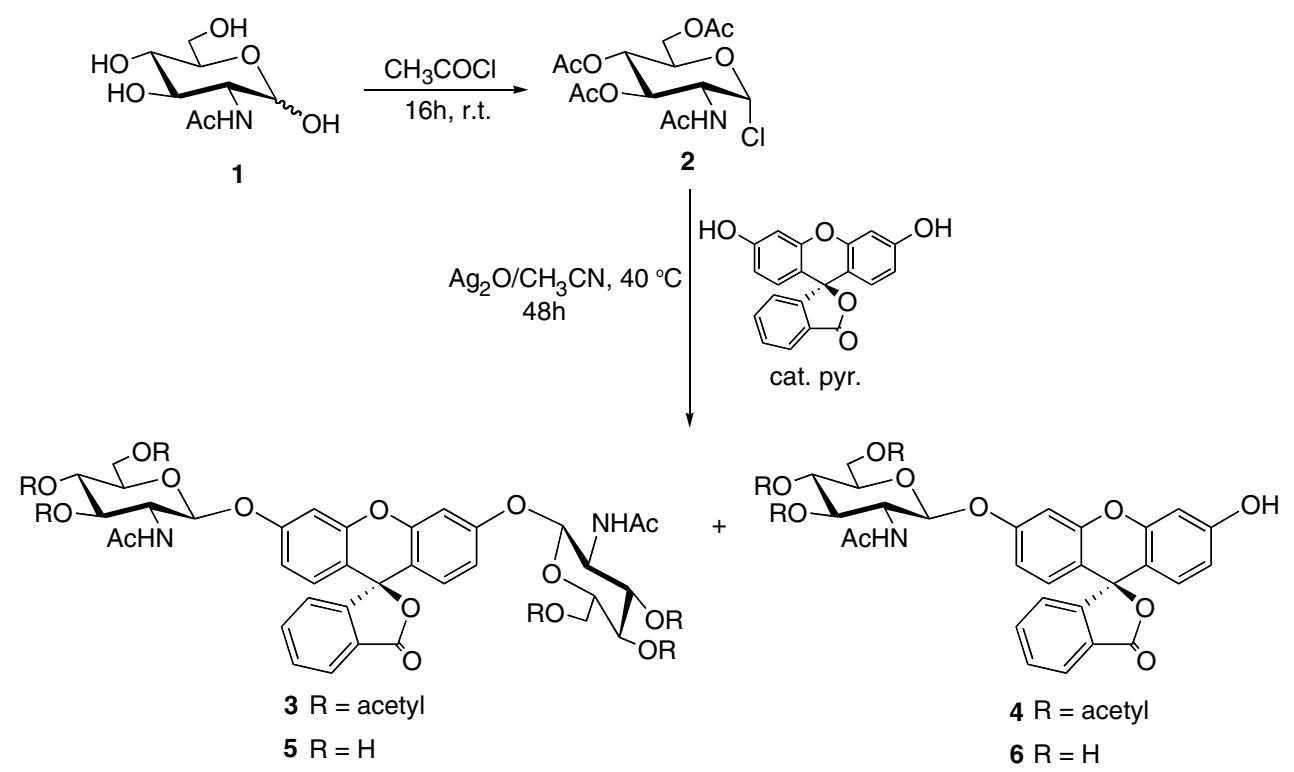

Scheme 1. Synthesis of fluorescein di( $N$-acetyl- $\beta$-D-glucosaminide) (FDGlcNAc). The synthesis of FDGlcNAc was carried out essentially according to the procedure described by Kasai et al. ${ }^{47}$ with some modifications; see details in the Experimental.

rescein was chosen as a fluorophore than when 4-methylumbelliferone was chosen. Therefore, we have selected fluorescein as the backbone of our substrate to achieve high sensitivity of the assay and prepared fluorescein, di- $N$-acetyl- $\beta$-D-glucosaminide (FDGlcNAc). The synthesis of FDGlcNAc was carried out according to the procedure described by Kasai et al. ${ }^{47}$ with some modifications. In this article, we evaluate the usefulness of FDGlcNAc as a new fluorogenic substrate for the study of both $O$-GlcNAcase isoforms by measuring their kinetic parameters. This fluorogenic substrate becomes fluorescent only upon cleavage by $O$-GlcNAcase. Due to the improved sensitivity of this substrate, we report that shorter splice variant is an active $O$-GlcNAcase (Scheme 1).

\section{Results and discussion}

The $O$-GlcNAc specific $\beta$ - $N$-acetylglucosaminidase $(O$ GlcNAcase) is involved in $O$-GlcNAc removal, playing a key role in $O$-GlcNAc metabolism. For example, $O$ (2-acetamido-2-deoxy-D-glucopyranosylidene)amino- $N$ phenylcarbamate (PUGNAC), a potent inhibitor of the $O$-GlcNAcase, blocks $O$-GlcNAc cycling, and induces insulin resistance. ${ }^{2,48-51}$ As mentioned before, the human MGEA5 gene produces alternatively spliced transcripts resulting in two isoforms. One is a full-length enzyme with a unique $\mathrm{C}$-terminal region considered as a putative histone acetyltransferase domain ${ }^{36}$ and the other is a shorter enzyme that does not have this unique C-terminal region. To date, active $O$-GlcNAcase has been recognized in only the longer isoform. The report ${ }^{52}$ that a single nucleotide polymorphism in the MGEA5 gene encoding $O$-GlcNAcase is associated with diabetes mellitus and age of onset in the Mexican-American population highlights the importance of the physiological role of $O$-GlcNAcase. Growing interest in $O$-GlcNAcase stimulated the need for a highly sensitive enzymatic assay method. A series of 4-methylumbelliferyl 2deoxy-2- $N$-fluoroacetyl $\beta$-D-glucopyranoside substrates for $O$-GlcNAcase were recently prepared by Vocadlo and co-workers. ${ }^{37}$ Because a fluorescein-conjugated substrate has higher sensitivity than the corresponding methylumbelliferyl substrate, ${ }^{45}$ fluorescein was selected as the aglycone of the synthetic fluorogenic substrate.

$O$-GlcNAcase exhibits both stereo and substrate specificities. This enzyme catalyzes the hydrolysis of $\beta-O$ linked $p$ NP-GlcNAc, but not $\alpha$ - $O$-linked $p$ NP-GlcNAc. Neither $\beta$-O-linked $p$ NP-GalNAc, nor para-nitrophenyl gluocopyranoaminide was cleaved by the enzyme (data not shown). Therefore, fluorescein conjugated to two $O$-GlcNAc moieties via $\beta$-linkages, $\mathbf{5}$, was designed as a substrate for $O$-GlcNAcase.

The synthesis of $2^{\prime}, 7^{\prime}$-dichlorofluorescein, di- $N$-acetyl$\beta$-D-glucosaminide and its use as a substrate for the colorimetric rate-assay of urinary $N$-acetyl $\beta$-D-gluocosaminidase (NAGase, EC 3.2.1.30) was originally reported by Kasai et al. ${ }^{47}$ In the conditions they developed for glycosidation, acetonitrile was used as a solvent and either $\mathrm{Et}_{3} \mathrm{~N}$ or silver oxide $\left(\mathrm{Ag}_{2} \mathrm{O}\right)$ was used as a catalyst. In the optimal reaction system, two GlcNAc moieties were conjugated into a dichloro derivative of fluorescein in a moderate yield ${ }^{47}$ However, when fluorescein was used as the aglycone, FDGlcNAc, which is the product of glycosylation of two hydroxyl groups in fluorescein, was not formed, possibly due to the weak reactivity of the secondary hydroxyl group in 
fluorescein. To overcome this obstacle, a small amount of base was used to increase the reactivity of the hydroxyl group in fluorescein. Thus, FDGlcNAc was successfully synthesized in moderate yield by treatment of fluorescein with a 3-fold molar quantity of 2-acetamido-3,4,6-tri- $O$-acetyl-2-deoxy- $\alpha$-D-glucopyranosyl chloride (2) as a glycosyl donor using acetonitrile as the solvent and silver oxide $\left(\mathrm{Ag}_{2} \mathrm{O}\right)$ as a catalyst in the presence of small amounts of pyridine at $40{ }^{\circ} \mathrm{C}$ for $48 \mathrm{~h}$. The two hydrophilic GlcNAc moieties of FDGlcNAc provide enhanced solubility $(>100 \mathrm{mM})$ compared to that of the conventional $p$ NP-GlcNAc $(<10 \mathrm{mM})$.

For the purpose of affinity purification and immunological identification, six consecutive histidine residues were recombinantly fused to the $O$-GlcNAcase, and its variant, at the N-terminus. These recombinant $O$ GlcNAcase and $v$-O-GlcNAcase proteins were expressed in Escherichia coli and purified on a nickel column via the $\mathrm{His}_{6}$-tag. To obtain relatively pure protein, an optimized washing protocol was employed (see Methods). The $v$-O-GlcNAcase eluted with a lower concentration $(60 \mathrm{mM})$ of imidazole as compared to full-length $O$ GlcNAcase $(300 \mathrm{mM})$. The flow-through fractions containing protein were assayed with two substrates, $p$ NP- $\beta$-GlcNAc and FDGlcNAc. The fractions containing enzymatic activity were concentrated with Microcon centrifugal filter devices (Microcon YM-100 and YM-50 for $O$-GlcNAcase and $v$-O-GlcNAcase, respectively) and the concentrated enzymes were reconstituted in $20 \mathrm{mM}$ Tris- $\mathrm{HCl}$, pH 7.5, $1 \mathrm{mM}$ DTT aqueous solution. Their purity was assessed by Ponceau staining and immunoblotting (Fig. 1). Recombinant $\mathrm{His}_{6}$-tagged-OGlcNAcase and $-v$-O-GlcNAcase migrated at their apparent molecular weight of $\sim 130$ and $\sim 80 \mathrm{kDa}$, respectively. Additionally the modified washing protocol was essential to produce sufficiently pure $\mathrm{His}_{6}$-tagged enzymes.

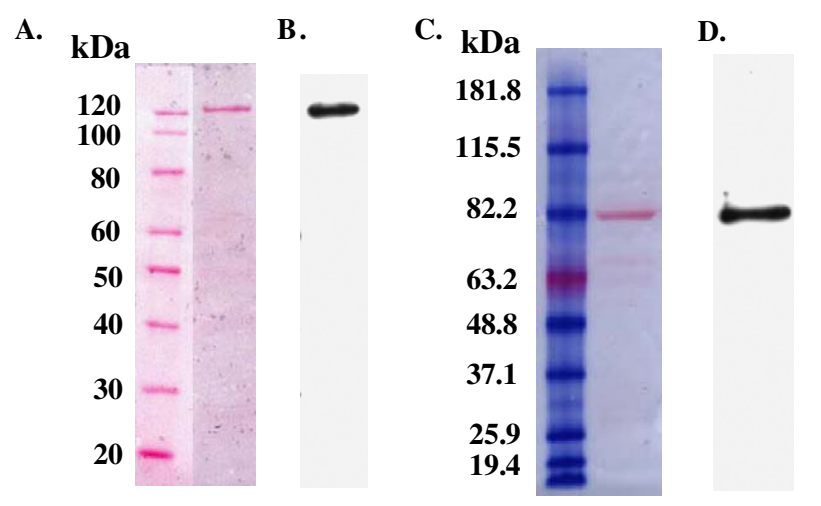

Figure 1. Isolation of $O$-GlcNAcase and $v-O$-GlcNAcase. The purity of $O$-GlcNAcase and $v$-O-GlcNAcase was confirmed by Ponceau $\mathrm{S}$ staining of the nitrocellulose membranes $(\mathrm{A}, \mathrm{C})$ and Western blot analysis using mouse HRP conjugated 6X His tag antibody [AD1.1.10] (B, D), respectively.
Neither $O$-GlcNAcase nor $v$ - $O$-GlcNAcase cleaved $\beta$ $\mathrm{O}$-glycosidic linkage of FDGalNAc. This result is consistent with previous findings that $O$-GlcNAcase has substrate specificity for $O$-GlcNAc but not $O$-GalNAc.

FDGlcNAc is nonfluorescent until cleavage of the $\beta$-D- $O$-glycosidic bond by either $O$-GlcNAcase or $v$-O-GlcNAcase. Spontaneous hydrolysis of FDGlcNAc was not observed, demonstrating that FDGlcNAc is as stable in aqueous solution (data not shown) as other substrates such as $p$ NP- $\beta-$ GlcNAc and MUGlcNAc. Enzymatic hydrolysis produces fluorescent fluorescein mono( $N$-acetyl- $\beta$-D-gluocosaminide) (FMGlcNAc), which is released from FDGlcNAc, tautomerizes to the quinoid form and generates fluorescence (Scheme 2). FMGlcNAc is then further hydrolyzed by the action of enzyme giving rise to fluorescein at longer time (Scheme 2 ). The products generated by enzymatic hydrolysis of FDGlcNAc were examined by LC-ESI (Fig. 2). A single peak representing FDGlcNAc $\left(t_{\mathrm{R}}=17.8 \mathrm{~min}\right)$ confirms that it is the only species present prior to addition of enzyme (Fig. 2A). All of the enzymatic assays performed were stopped when less than $5 \%$ of FDGlcNAc was utilized. As expected, during the time frame of our kinetic assay, FMGlcNAc $\left(t_{\mathrm{R}}=20.0 \mathrm{~min}\right)$ was the only fluorescent species generated by the enzymatic hydrolysis and fluorescence was due to the accumulation of FMGlcNAc alone (Fig. 2B). When 2-fold more enzyme is used and incubation time is extended, the fluorescein $\left(t_{\mathrm{R}}=\right.$ $24.0 \mathrm{~min}$ ) released upon cleavage of the second $\mathrm{N}$-acetyl- $\beta$-D-glucosaminyl group from further hydrolysis of FMGlcNAc was detected (Fig. 2C). However, during the timeframe of our assay for measuring initial velocities of enzymatic hydrolysis with varying concentrations of FDGlcNAc and predetermined amounts of enzyme, only one of the $N$-acetyl- $\beta$-D-gluocosaminyl groups was cleaved from the substrate producing fluorescent FMGlcNAc. Given these data, we used FMGlcNAc as the standard for kinetics of the $O$-GlcNAcase enzymatic reaction. When the fluorometer was set to have excitation and emission wavelengths at 485 and $535 \mathrm{~nm}$, respectively, with the $4 \mathrm{~mm}$ diameter of circular aperture and $1 \mathrm{~s}$ of counting time, a plot of increasing concentrations of FMGlcNAc up to $12 \mu \mathrm{M}$ versus their fluorescence intensities (relative fluorescence units, RFU) resulted in a linear correlation. From this plot the calculated molar fluorescence constant of FMGlcNAc was 119,820 units/ $\mu \mathrm{M}$.

Utilizing FDGlcNAc as a substrate, kinetic parameters including Michaelis constants $\left(K_{\mathrm{m}}\right)$, specific activities, turnover numbers, and enzymatic efficiencies of the recombinant $O$-GlcNAcase were obtained through Lineweaver-Burk plots (Fig. 3). Surprisingly, incubation of FDGlcNAc with the $v$ - $O$-GlcNAcase also produced fluorescence, indicating that this is an active enzyme. The kinetic parameters of the variant enzyme were calculated as well (Fig. 4). For the comparison of 


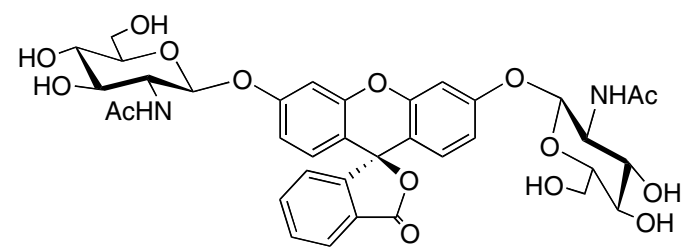

5

O-GIcNAcase or $v$-O-GIcNAcase

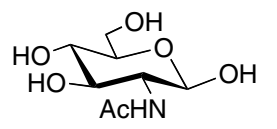

1
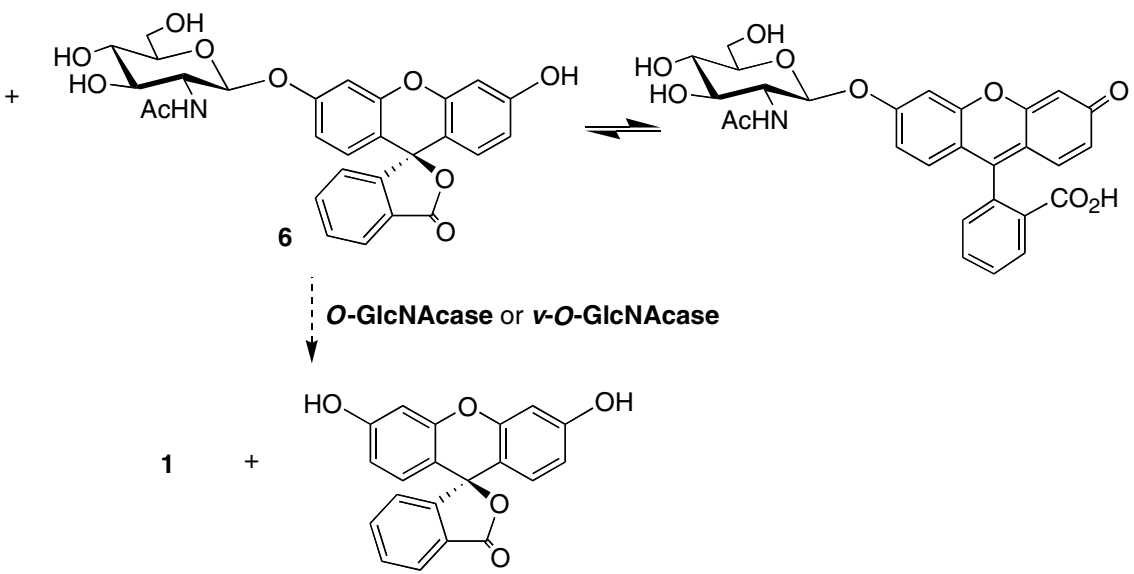

Scheme 2. Enzymatic hydrolysis reaction of FDGlcNAc (5) by either $O$-GlcNAcase or $v$ - $O$-GlcNAcase. FMGlcNAc accumulated at the initial stage of enzymatic hydrolysis. However, fluorescein can be formed under conditions of higher enzyme concentration or longer reaction times.

these kinetic parameters with FDGlcNAc, enzymes were assayed with $p$ NP- $\beta$-GlcNAc (Fig. 5) and the kinetic values of both enzymes for FDGlcNAc and $p$ NP- $\beta$-GlcNAc are summarized in Table 1. Using the FDGlcNAc substrate, we established that $O$-GlcNAcase has a $K_{\mathrm{m}}$ of $85 \mu \mathrm{M}$ and a specific activity of $780 \mathrm{nmol} / \mathrm{min} / \mathrm{mg}$ with a turnover rate of $1.3 / \mathrm{s}$. Catalytic efficiency $\left(K_{\text {cat }} / K_{\mathrm{m}}\right)$ of $O$-GlcNAcase for FDGlcNAc was $1.6 \times 10^{4} \mathrm{M}^{-1} \mathrm{~s}^{-1}$. On the other hand, $O$-GlcNAcase exhibited a $K_{\mathrm{m}}$ of $1.1 \mathrm{mM}$ and a specific activity of $2035 \mathrm{nmol} / \mathrm{min} / \mathrm{mg}$ with a turnover number of approximately $3 / \mathrm{s}$ and catalytic efficiency of $3.0 \times 10^{3} \mathrm{M}^{-1} \mathrm{~s}^{-1}$ for $p$ NP- $\beta$-GlcNAc.

The low $K_{\mathrm{m}}$ and high affinity of $O$-GlcNAcase for FDGlcNAc can be explained by the rigidity and hydrophobicity of the aglycone fluorescein. The respective increase in both the hydrophobicity and rigidity between the three substrates $p$ NP- $\beta$-GlcNAc, MUGlcNAc, and FDGlcNAc may reflect an associated decrease in the $K_{\mathrm{m}}$ values for these substrates and an increase in apparent affinity. The affinity of $O$-GlcNAcase for FDGlcNAc $\left(K_{\mathrm{m}}=85 \mu \mathrm{M}\right)$ is about 13-fold stronger than it is for $p$ NP- $\beta$-GlcNAc $\left(K_{\mathrm{m}}=1.1 \mathrm{mM}\right)$ and 5 -fold stronger than it is for the fluorogenic substrate ${ }^{45}\left(K_{\mathrm{m}}=430 \mu \mathrm{M}\right)$. The most hydrophobic aglycone, fluorescein, is thought to mimic the rigid serine and threonine residues found in proteins. $O$-GlcNAcaes can access this constrained and hydrophobic substrate better than MUGlcNAc and the least constrained substrate $p \mathrm{NP}-\beta-\mathrm{GlcNAc}$.
While our $K_{\mathrm{m}}$ value of $O$-GlcNAcase for $p$ NP- $\beta$-GlcNAc was in good agreement with previous reports, ${ }^{40}$ the specific activity differed. The specific activity of our recombinant enzyme for $p$ NP- $\beta-G l c N A c$ was found to be $2035 \mathrm{nmol} / \mathrm{min} / \mathrm{mg}$ whereas the reported value of their recombinant $O$-GlcNAcase for the $p$ NP- $\beta$-GlcNAc substrate was $652 \mathrm{nmol} / \mathrm{min} / \mathrm{mg}$. ${ }^{40}$ In contrast to the $K_{\mathrm{m}}$, specific activity is not a constant value and depends on the enzymatic assay conditions as well as the purity of enzymes. Wells et al. ${ }^{40}$ used $50 \mathrm{mM}$ sodium cacodylate, pH 6.5 as an assay buffer for measuring $O$-GlcNAcase activity whereas $O$-GlcNAcase activity was assayed in $100 \mathrm{mM}$ citrate phosphate buffer, pH 6.5 in our kinetic experiments. Furthermore, recombinant $O$ GlcNAcase enzymes have different tags. The cloned human $O$-GlcNAcase used in our assays has a small tag composed of six histidine amino acids, while recombinant $O$-GlcNAcase used in their assay has a thioredoxin tag. Thioredoxin is an approximately $10 \mathrm{kDa}$ protein and its presence may reduce $O$-GlcNAcase catalytic activity. It is likely that a small oligopeptide such as a six consecutive histidine residue does not significantly affect the catalytic activity of $O$-GlcNAcase. Because the specific activity of our recombinant $O$-GlcNAcase for $p$ NP- $\beta$-GlcNAc is about 3 -fold greater than that reported previously, ${ }^{40}$ other kinetic parameters such as turnover number and catalytic efficiency that are dependent on specific activity value are also 3 -fold higher. 
C.

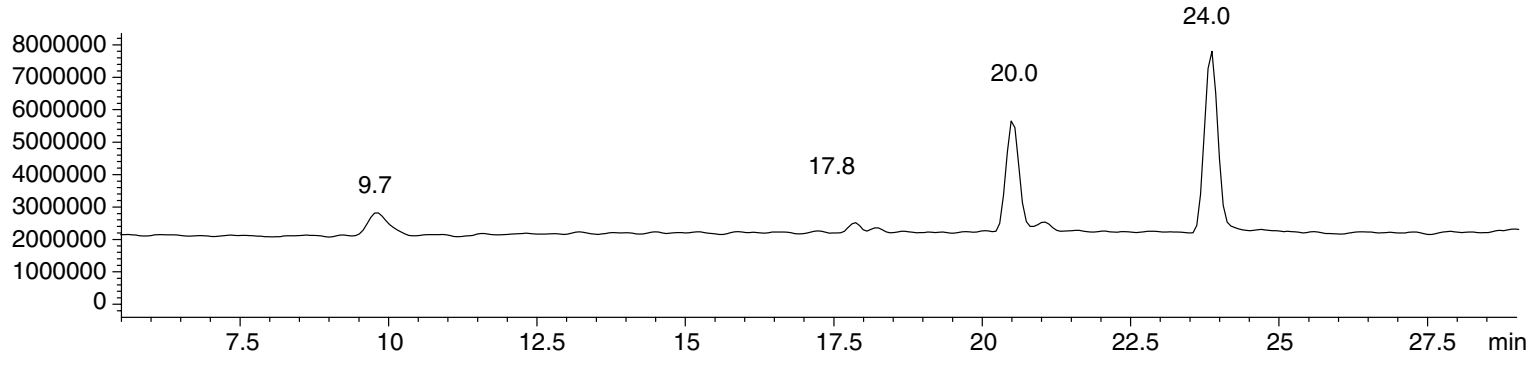

B.

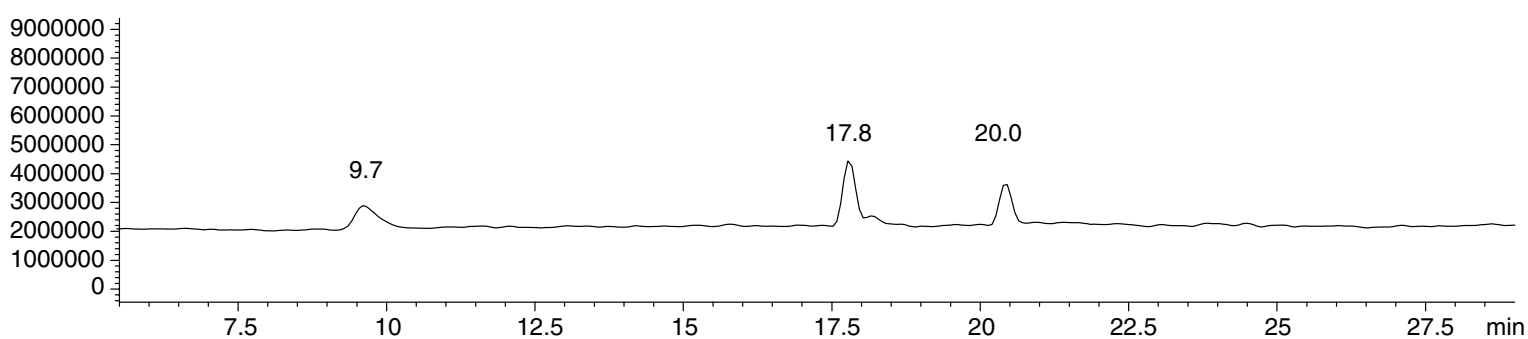

A.

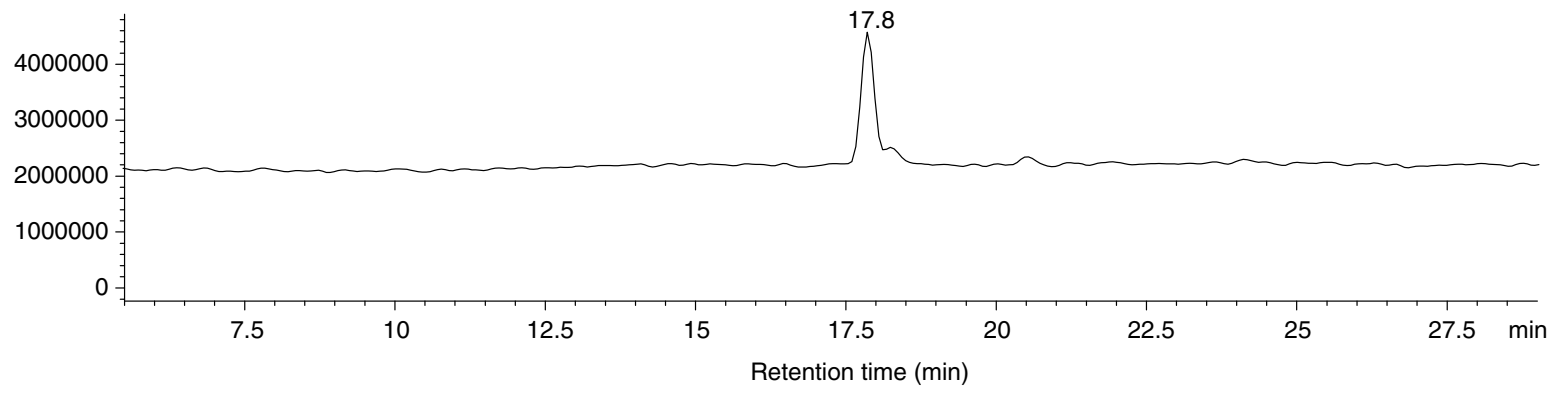

Figure 2. Enzymatic hydrolysis of FDGlcNAc examined by LC-ESI. LC conditions are as follows: flow rate, $0.2 \mathrm{~mL} / \mathrm{min}$; isocratic elution of $\mathrm{H}_{2} \mathrm{O} /$ $\mathrm{CH}_{3} \mathrm{CN}(\mathrm{v} / \mathrm{v}), 97: 3$ for $5 \mathrm{~min}$, then a gradient of $\mathrm{H}_{2} \mathrm{O} / \mathrm{CH}_{3} \mathrm{CN}(\mathrm{v} / \mathrm{v})$, from 97:3 to 2:98 for 40 min. (A) A chromatogram of FDGlcNAc $\left(t_{\mathrm{R}}=17.8 \mathrm{~min}\right)$ in the absence of $O$-GlcNAcase. (B) New peaks arising after a $10 \mathrm{~min}$ incubation with $O$-GlcNAcase $(2 \mu \mathrm{L})$ at $37{ }^{\circ} \mathrm{C}$ are due to GlcNAc $\left(t_{\mathrm{R}}=9.7 \mathrm{~min}\right)$ and FMGlcNAc $\left(t_{\mathrm{R}}=20.0 \mathrm{~min}\right)$, respectively. $(\mathrm{C})$ A chromatogram of FDGlcNAc incubated with $O$-GlcNAcase $(4 \mu \mathrm{L})$ at $37^{\circ} \mathrm{C}$ for $7 \mathrm{~h}$. Fluorescein is detected and has a retention time of $24 \mathrm{~min}$.

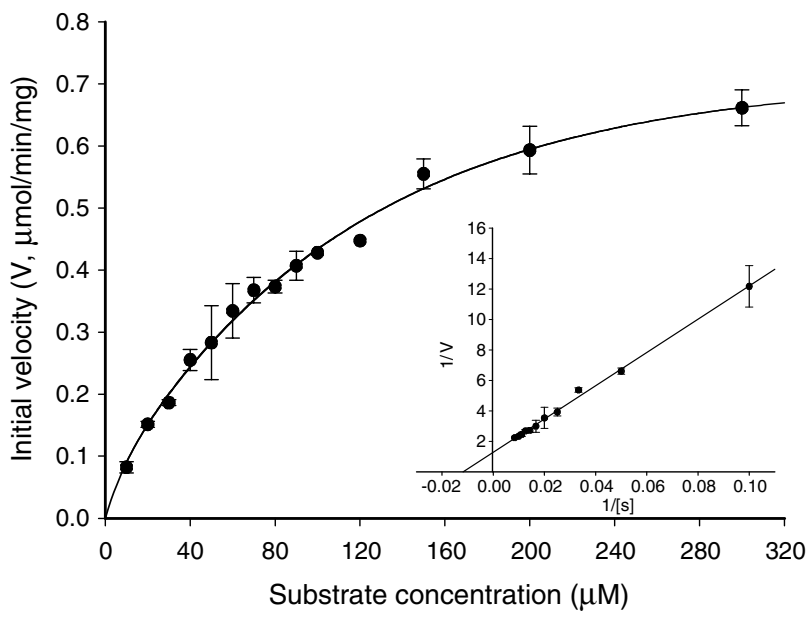

Figure 3. Enzyme kinetics of full-length $O$-GlcNAcase. An activity curve and a Lineweaver-Burk plot were generated for recombinant $O$ GlcNAcase by varying concentrations of the substrate, FDGlcNAc.

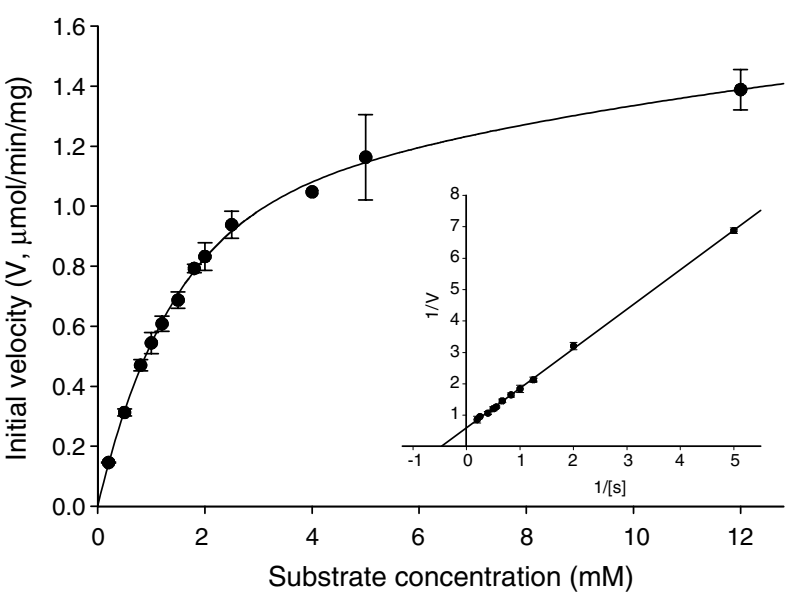

Figure 4. Enzyme kinetics of variant $O$-GlcNAcase. An activity curve and a Lineweaver-Burk plot were generated for recombinant $v-O$ GlcNAcase by varying concentrations of the substrate, FDGlcNAc. 


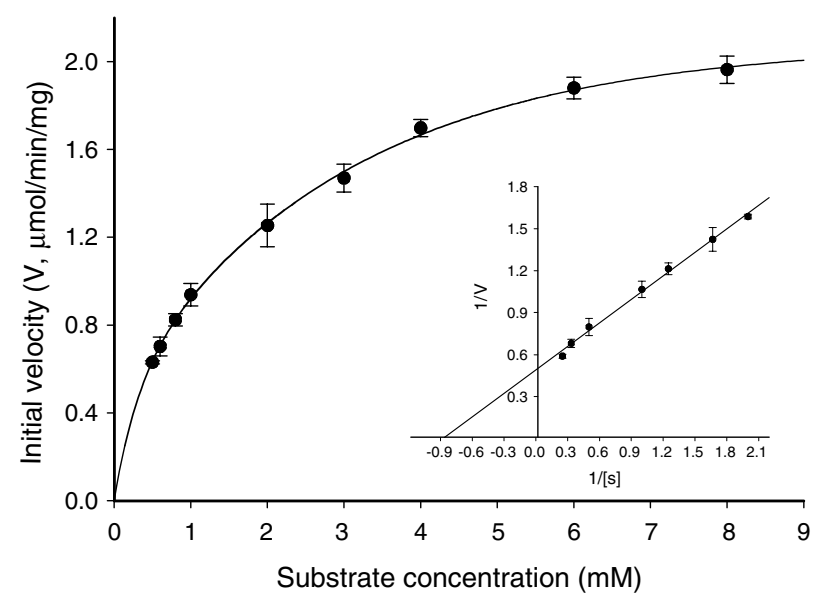

Figure 5. Enzyme kinetics of $O$-GlcNAcase. An activity curve and a Lineweaver-Burk plot were generated for recombinant $O$-GlcNAcase by varying concentrations of the substrate, $p$ NP- $\beta$-GlcNAc.

Interestingly, $O$-GlcNAcase purified from bovine brain was reported ${ }^{27}$ to exhibit a specific activity $(1840 \mathrm{nmol} / \mathrm{min} / \mathrm{mg})$ similar to the specific activity reported here.

Previous reports using $p$ NP- $\beta$-GlcNAc (up to $8 \mathrm{mM}$ ) as a substrate, did not detect activity of the shorter $O$-GlcNAcase splice variant. ${ }^{40}$ However, using FDGlcNAc we found that $v$-O-GlcNAcase has a $K_{\mathrm{m}}$ of $2.1 \mathrm{mM}$ and a specific activity of $1680 \mathrm{nmol} / \mathrm{min} / \mathrm{mg}$ with a turnover rate of 2.1. The catalytic efficiency of this shorter isoform for FDGlcNAc was determined to be $1.0 \times 10^{4} \mathrm{M}^{-1} \mathrm{~s}^{-1}$. The activity detected with the shorter $O$-GlcNAcase was unanticipated. There has been controversy regarding the catalytic region of $O$-GlcNAcase. ${ }^{35,38-40}$ As previously mentioned, the $\mathrm{C}$-terminal domain of $O$-GlcNAcase is homologous to acetyltransferases domain and is absent in $v$-O-GlcNAcase. Instead, this acetyltransferase domain is replaced by a novel 15 amino acid tail in the variant. Although Hanover et al. ${ }^{38}$ and Rigden et al. ${ }^{39}$ proposed that the catalytic domain of $O$-GlcNAcase is likely to be located in the N-terminal region, there have been no empirical data that support this proposal. On the contrary, the lack of enzymatic activity in the shorter isoform led to such a conclusion that $v$-O-GlcNAcase is not active, therefore, the $O$-GlcNAcase catalytic domain resides at the C-terminal end of enzyme. ${ }^{35,40}$ However, our in vitro kinetic data suggest that $v-O$-GlcNAcase is quite active, although the $K_{\mathrm{m}}$ value of $v$-O-GlcNAcase for FDGlcNAc was 25-fold higher than that of the fulllength $O$-GlcNAcase.

To further confirm that the shorter $O$-GlcNAcase is active, a mixed population of substrates from both HT-29 and HeLa cell extracts were incubated with either $O$-GlcNAcase or $v$-O-GlcNAcase as described under Experimental. As shown in Figure 6A, treatment of HT-29 cell extracts with either $O$-GlcNAcase (lane 3 and 4) or its shorter isoform (lane 5) decreased the level of $O$-GlcNAc-modified proteins compared to that of cell extracts treated with no enzyme (lane 2). Given the differences in enzymatic kinetics between the two enzymes (Table 1), it was not surprising that $v$-O-GlcNAcase did not lower the levels of $O$-GlcNAc as well as did fulllength $O$-GlcNAcase. Similar results were obtained from HeLa cell extracts (Fig. 6B). These findings suggest that both the full-length and variant $O$-GlcNAcases are active against cellular $O$-GlcNAc-modified substrates confirming our earlier in vitro data using FDGlcNAc. Based on these data, $v$ - $O$-GlcNAcase activity should be detected using much higher concentrations of $p$ NP$\beta$-GlcNAc. Given the fact that this shorter isoform is a bona fide $O$-GlcNAcase and does not possess the
A.

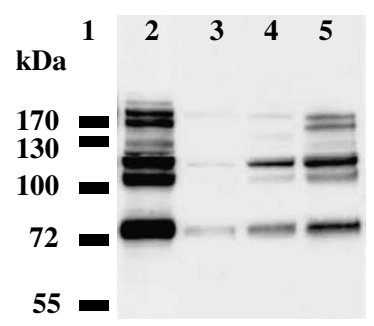

B.

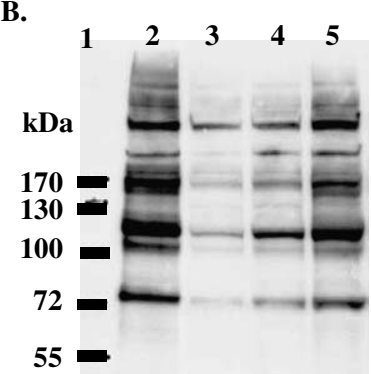

Figure 6. Enzymatic activity of $O$-GlcNAcase and $v$ - $O$-GlcNAcase on mixed substrates. Western blot analysis of HT-29 (A) and HeLa (B) cell extracts treated with either $O$-GlcNAcase or $v$-O-GlcNAcase. Lane 1 , protein marker; lane 2, cell extracts without enzyme (control); lanes 3 and 4 , cell extracts treated with 7 and $5 \mu \mathrm{g}$ of $O$-GlcNAcase, respectively; and lane 5 , cell extracts treated with $5 \mu \mathrm{g}$ of $v$-O-GlcNAcase.

Table 1. Kinetic parameters of both recombinant $O$-GlcNAcase isoforms for FDGlcNAc, $\mathbf{5}$, and $p N P-\beta$-GlcNAc

\begin{tabular}{llll}
\hline Kinetic parameter & Substrate & Enzyme \\
\cline { 2 - 3 } & & $O$-GlcNAcase & $v$ - $O$-GlcNAcase \\
\hline$K_{\mathrm{m}}(\mathrm{mM})$ & FDGGlcNAc & $0.085 \pm 0.016$ & $2.1 \pm 0.2$ \\
Specific activities $(\mathrm{nmol} / \mathrm{min} / \mathrm{mg})$ & $p$ NP- $\beta$-GlcNAc & $1.1 \pm 0.1$ & - \\
& FDGGlcNAc & $780 \pm 60$ & $1680 \pm 165$ \\
Turnover number $\left(K_{\mathrm{cat}}, \mathrm{s}^{-1}\right)$ & $p$ NP- $\beta$-GlcNAc & $2035 \pm 161$ & - \\
& FDGGlcNAc & $1.3 \pm 0.1$ & $2.1 \pm 0.2$ \\
$K_{\mathrm{cat}} / K_{\mathrm{m}}\left(\right.$ efficiency, $\left.\mathrm{M}^{-1} \mathrm{~s}^{-1}\right)$ & $p$ NP- $\beta$-GlcNAc & $3.4 \pm 0.3$ & - \\
& FDGGlcNAc & $1.6 \times 10^{4}$ & $1.0 \times 10^{3}$ \\
\hline
\end{tabular}


C-terminal histone acetyl transferase domain, it is likely that the $O$-GlcNAcase catalytic domain is located in the common N-terminal domain that has homology to $\mathrm{Mu}$ toxin. ${ }^{38}$ Some evidence suggests that the full-length $O$-GlcNAcase might be a bifunctional enzyme capable of both catalyzing the hydrolysis of $\beta$-linked GlcNAc and catalyzing acetylation of histones. ${ }^{36}$ Because there has been no tool to measure the enzymatic activity in $v$-O-GlcNAcase, it is not clear what function this shorter isoform serves in a cellular context. One hypothesis is that it serves as a regulatory tool in concert with the full-length of $O$-GlcNAcase. ${ }^{40}$

The nature of FDGlcNAc made it an extremely sensitive substrate for $O$-GlcNAcase enabling the detection of enzymatic activity in $v$-O-GlcNAcase for the first time. In conclusion, FDGlcNAc has several advantages for the study of both $O$-GlcNAcase isoforms over the conventional substrate, $p$ NP- $\beta-G 1 c N A c$ and the precedent fluorogenic substrate, MUGlcNAc, ${ }^{37}$ in terms of sensitivity of the assay and the affinity for the enzyme. In addition, a high-throughput analysis is possible using a multiwell plate format with this new substrate. To dissect the role of each $O$-GlcNAcase isoform, it is necessary to find specific inhibitors of full-length $O$ GlcNAcase over its shorter isoform or vice versa. The high-throughput assay with this highly sensitive fluorogenic substrate, FDGlcNAc will accelerate the discovery of novel $O$-GlcNAcase inhibitors. The highly sensitive substrate FDGlcNAc made it possible to confirm that the $v-O$-GlcNAcase as an active enzyme. The functional role of each $O$-GlcNAcase isoform is currently under active investigation. Although FDGlcNAc is cell permeable, its use in intact cells as an imaging agent for the in vivo analysis of $O$-GlcNAcase is limited due to the lack of enzyme specificity between $O$-GlcNAcase and lysosomal hexosaminidases. We are currently developing fluorogenic substrates, which are specific for only $O$-GlcNAcase but not lysosomal hexosaminidases.

\section{Experimental}

\subsection{General methods}

All chemicals were of reagent grade and purchased from Sigma Chemical Co. unless otherwise noted. Deuterated DMSO was from Cambridge Isotope Laboratories. FDGalNAc was purchased from Marker Gene Technologies, Inc. Acetonitrile was dried over $4 \AA$ molecular sieves overnight prior to use. The Inertsil ODS- 2 column was obtained from GL Science Inc. ${ }^{1} \mathrm{H}$ NMR and ${ }^{13} \mathrm{C}$ NMR spectra were recorded at 300 and $75 \mathrm{MHz}$, respectively, with a Varian Mercury 300 spectrometer. Chemical shifts are reported in parts per million $(\delta)$ and referenced to either the residual signal of the solvent used (DMSO: ${ }^{1} \mathrm{H} \delta$ 2.50) or internal tetramethylsilane.
Coupling constants, $J$, are reported in Hertz. Analytical thin-layer chromatography (TLC) was conducted on Silica Gel 60-F254 (E. Merck) with detection by UV light and/or dipping the plates in a cerium sulfate-ammonium molybdate solution followed by heating. Flash column chromatography was carried out on Merck Kiesel gel $60\left(\mathrm{SiO}_{2}, 230-400\right.$ mesh). High performance liquid chromatography (HPLC) was performed on an Inertsil ODS-2 column $(10 \mathrm{~mm}$ i.d. $\times 250 \mathrm{~mm})$ using a Hewlett Packard Series 1100 multisolvent delivery system with a multiple wavelength detector (flow rate, $2 \mathrm{~mL} / \mathrm{min}$; detection, 254, $280 \mathrm{~nm}$; temperature, ambient). Fast atom bombardment $\left(\mathrm{FAB}^{+}\right) \mathrm{MS}$ was obtained at the National Institutes of Health Mass Spectrometry Laboratory. High resolution-electrospray ionization (HRESI) mass spectrum was obtained on a Waters LCT Premier time-of-flight (TOF) mass spectrometer. Combined liquid chromatography and electrospray ionization (LC-ESI) mass spectra were obtained on Hewlett Packard Series 1100 MSD equipped with HPLC performed on an Atlantis ${ }^{\mathrm{TM}} \mathrm{dC}_{18}$ column $(2.1 \mathrm{~mm}$ i.d. $\times 100 \mathrm{~mm})$ at the National Institutes of Health Mass Spectrometry Laboratory. Elemental analyses were obtained at Atlantic Microlab, Inc. Fluorometry measurements were obtained at wavelengths of 485 and $535 \mathrm{~nm}$ for fluorescence excitation and emission, respectively, with Wallac 1420 multilabel counter (Perkin-Elmer Life Sciences). Absorbance was measured at $400 \mathrm{~nm}$ with a UV 160U spectrophotometer (Shimadzu).

\section{2. $3^{\prime}, 6^{\prime}$-Bis $[\mid 3,4,6$-tri- $O$-acetyl-2-(acetylamino)-2-deoxy- $\beta$-D-glucopyranosyl]oxy]-spiro[isobenzofuran-1(3H), $9^{\prime}$-[9H]-xanthen]-3-one (3)}

Fluorescein $(1.0 \mathrm{~g}, 3 \mathrm{mmol})$ was added to a solution of $\mathrm{N}$-acetyl 2-deoxy-3,4,6-tri- $O$-acetyl- $\alpha$-D-glucopyranosyl chloride $^{53}(2,3.3 \mathrm{~g}, 9.0 \mathrm{mmol})$ in dry $\mathrm{CH}_{3} \mathrm{CN}$. To this mixture were, subsequently, added silver oxide $\left(\mathrm{Ag}_{2} \mathrm{O}\right.$, $2.09 \mathrm{~g}, 9.0 \mathrm{mmol}$ ) and five drops of pyridine. The reaction solution was stirred for 2 days at $40^{\circ} \mathrm{C}$, after which the remaining solid residue was removed by filtration and the filtrate was concentrated to yield a dark brown syrup. Flash column silica chromatography of the resulting residue washing with a mixture of hexane/EtOAc (2:1), then eluting with a gradient of $\mathrm{CHCl}_{3} / \mathrm{CH}_{3} \mathrm{CN}$ from $1: 1$ to $1: 2(\mathrm{v} / \mathrm{v})$ offered the desired product 3 as a white solid $(1.19 \mathrm{~g}, 1.2 \mathrm{mmol}, 40 \%): R_{\mathrm{f}}=0.12(\mathrm{EtOAc}) ;{ }^{1} \mathrm{H}$ NMR (300 MHz, DMSO- $d_{6}$ ): $\delta 8.08$ (app. dd, 2H, $J=8.7,2.7 \mathrm{~Hz}$, arom $\mathrm{H}), 8.03(\mathrm{~d}, 2 \mathrm{H}, J=7.2 \mathrm{~Hz}$, $\mathrm{NHCOCH}$ ), $7.80(\mathrm{dt}, 1 \mathrm{H}, J=7.6,1.5 \mathrm{~Hz}$, arom $\mathrm{H})$, $7.74(\mathrm{dt}, 1 \mathrm{H}, J=7.2,1.1 \mathrm{~Hz}$, arom $\mathrm{H}), 7.31(\mathrm{~d}, 1 \mathrm{H}$, $J=7.6 \mathrm{~Hz}$, arom $\mathrm{H}), 7.03(\mathrm{dd}, 2 \mathrm{H}, J=5.3,2.0 \mathrm{~Hz}$, xanthene $\mathrm{H}), 6.81-6.72(\mathrm{~m}, 4 \mathrm{H}$, xanthene $\mathrm{H}), 5.44(\mathrm{~d}, 2 \mathrm{H}$, $J=8.4 \mathrm{~Hz}$, GlcNAc H-1), 5.24 (app. dt, $2 \mathrm{H}, J=9.7$, $3.0 \mathrm{~Hz}, \mathrm{GlcNAc} \mathrm{H}-3), 4.94$ (t, $2 \mathrm{H}, J=9.5 \mathrm{~Hz}$, GlcNAc H-4), 4.25-3.96 (m, 8H, GlcNAc H-5, H-6a, H-6b, H- 
2), 2.06, $2.03\left(\mathrm{~s}\right.$, each $\left.3 \mathrm{H}, \mathrm{OCOCH}_{3}\right), 2.01,1.96$ (s, each $\left.6 \mathrm{H}, \mathrm{OCOCH}_{3}\right), 1.78,1.77$ (s, each $\left.3 \mathrm{H}, \mathrm{NHCOCH}_{3}\right) ;{ }^{13} \mathrm{C}$ NMR (75 MHz, DMSO- $\left.d_{6}\right): \delta 170.02,169.98,169.69$, $169.54,169.34,168.51(9 C=\mathrm{O}), 158.28,158.22,152.39$, 151.42, 151.39 (5C), 135.84 (arom $\mathrm{CH}$ ), 130.38 (arom $\mathrm{CH}$ ), 129.34 (xanthene, 2CH), 125.65 (1C), 124.86 (arom $\mathrm{CH}$ ), 124.00 (arom $\mathrm{CH}$ ), 113.86 (xanthene, $2 \mathrm{CH}$ ), 112.81, 112.87 (2C), 103.44 (xanthene, $2 \mathrm{CH}$ ), $97.50(2 \mathrm{CH}, \mathrm{C}-1), 81.58$ (xanthene, spiro C), 72.24 (2CH, C-3), $70.96(2 \mathrm{CH}, \mathrm{C}-5), 68.33(2 \mathrm{CH}, \mathrm{C}-4), 61.64$ (2CH, C-6), 53.05 (2CH, C-2), 20.34, 20.44, 20.48 $\left(6 \mathrm{CH}_{3}, \mathrm{COCH}_{3}\right), 22.62\left(2 \mathrm{CH}_{3}, \mathrm{NHCOCH}_{3}\right)$. Anal. Calcd for $\mathrm{C}_{48} \mathrm{H}_{50} \mathrm{~N}_{2} \mathrm{O}_{21} \cdot \mathrm{H}_{2} \mathrm{O}: \mathrm{C}, 57.14 ; \mathrm{H}, 5.19 ; \mathrm{N}$, 2.78. Found: C, 56.81; H, 5.18; N, 2.89 .

\section{3. $3^{\prime}$-[|3,4,6-Tri- $O$-acetyl-2-(acetylamino)-2-deoxy- $\beta$-D- glucopyranosyl]oxyl-6' ${ }^{\prime}$-hydroxyspiro[isobenzofuran- $1(3 H), 9^{\prime}-[9 H]$-xanthen]-3-one (4)}

Silver oxide $\left(\mathrm{Ag}_{2} \mathrm{O}, 0.28 \mathrm{~g}, 1.2 \mathrm{mmol}\right)$ and two drops of pyridine were added to a solution of $2(0.44 \mathrm{~g}, 1.2 \mathrm{mmol})$ and fluorescein $(0.2 \mathrm{~g}, 1.2 \mathrm{mmol})$ in dry $\mathrm{CH}_{3} \mathrm{CN}$. The reaction mixture was stirred for 2 days at $40{ }^{\circ} \mathrm{C}$, after which the remaining solid residue was removed by filtration. The filtrate was concentrated and subjected to flash column silica chromatography. Elution with a slow gradient of $\mathrm{CH}_{3} \mathrm{Cl} / \mathrm{CH}_{3} \mathrm{CN}$ from 2:1 to $1: 1(\mathrm{v} / \mathrm{v})$ gave $0.48 \mathrm{~g}$ of 4 as a yellow colored powder $(0.73 \mathrm{mmol}, 60 \%)$; $R_{\mathrm{f}}=0.47$ (EtOAc); ${ }^{1} \mathrm{H}$ NMR $\left(300 \mathrm{MHz}\right.$, DMSO- $\left.d_{6}\right): \delta$ 8.10 (app. dd, $1 \mathrm{H}, J=9.0,3.9 \mathrm{~Hz}$, arom $\mathrm{H}$ ), 8.01 (d, $\left.2 \mathrm{H}, J=6.9 \mathrm{~Hz}, \mathrm{NHCOCH}_{3}\right), 7.79-7.70(\mathrm{~m}, 2 \mathrm{H}$, arom $\mathrm{H}), 7.29$ (app. t, $1 \mathrm{H}, J=9.0 \mathrm{~Hz}$, arom $\mathrm{H}$ ), 7.09-7.07 $(\mathrm{m}, 1 \mathrm{H}$, xanthene $\mathrm{H}), 6.73-6.69(\mathrm{~m}, 3 \mathrm{H}$, xanthene $\mathrm{H})$, 6.60-6.58 (m, 2H, xanthene $\mathrm{H}), 5.43(\mathrm{~d}, 1 \mathrm{H}, J=$ $8.7 \mathrm{~Hz}$, GlcNAc H-1), 5.22, $5.21(\mathrm{t}$, each $1 / 2 \mathrm{H}, J=$ $9.8 \mathrm{~Hz}$, GlcNAc H-3), 4.92 (t, $1 \mathrm{H}, J=9.7 \mathrm{~Hz}$, GlcNAc H-4), 4.27-4.15 (m, 2H, GlcNAc H-5, H-6a), 4.15-3.98 (m, 2H, GlcNAc H-2, H-6b), 2.06, 2.04 (s, each $\left.3 / 2 \mathrm{H}, \mathrm{OCOCH}_{3}\right), 2.01,1.95$ ( s, each $3 \mathrm{H}, \mathrm{OCOCH}_{3}$ ), 1.77, 1.76 (s, each $3 / 2 \mathrm{H}, \mathrm{NHCOCH}_{3}$ ); LR LC-ESIMS: $m / z 684.2\left[\mathrm{M}+\mathrm{Na}^{+}\right]$.

\section{4. $3^{\prime}, 6^{\prime}$-Bis[[2-(acetylamino)-2-deoxy- $\beta$-D-glucopyran- osyl]oxy]-spiro-[isobenzofuran-1 $(3 H), 9^{\prime}-[9 H]$-xanthen]-3- one (5)}

A cooled $\left(-20^{\circ} \mathrm{C}\right)$ solution of $3(300 \mathrm{mg}, 0.30 \mathrm{mmol})$ in $\mathrm{CH}_{3} \mathrm{OH}(5 \mathrm{~mL})$ was treated dropwise with aqueous $\mathrm{NH}_{3}$ $(28 \%, 1 \mathrm{~mL}, 7.2 \mathrm{mmol})$. The reaction mixture was warmed to rt over $2 \mathrm{~h}$, stirred for an additional $1 \mathrm{~h}$ at $\mathrm{rt}$, and concentrated in vacuo to yield a pale yellow solid. This crude material was purified by reverse-phase HPLC to give 5 (170 $\mathrm{mg}, 0.23 \mathrm{mmol}, 76.7 \%)$ as a white solid: HPLC: $t_{\mathrm{R}}=16.8 \mathrm{~min}\left(\mathrm{H}_{2} \mathrm{O} / \mathrm{CH}_{3} \mathrm{CN}(\mathrm{v} / \mathrm{v})\right.$ from 95:5 to $80: 20$ for $5 \mathrm{~min}, 80: 20$ to $60: 40$ for $15 \mathrm{~min}$, 60:40 to $35: 65$ for $25 \mathrm{~min}, 2 \mathrm{~mL} / \mathrm{min}$ ); ${ }^{1} \mathrm{H} \mathrm{NMR}$
(300 MHz, DMSO- $\left.d_{6}\right): \delta 8.02(\mathrm{~d}, 1 \mathrm{H}, J=7.42 \mathrm{~Hz}$, arom $\mathrm{H}), 7.82-7.71\left(\mathrm{~m}, 4 \mathrm{H}, 2 \times \operatorname{arom~} \mathrm{H}, 2 \times \mathrm{NHCOCH}_{3}\right)$, $7.30(\mathrm{~d}, 1 \mathrm{H}, J=7.42 \mathrm{~Hz}$, arom $\mathrm{H}$ ), 6.96 (app. m, 2H, xanthene $\mathrm{H}$ ), 6.71 (app. s, 4H, xanthene $\mathrm{H}$ ), 5.14-5.09 (m, 6H, GlcNAc H-1, OH-3, OH-4), 4.65 (app. q, 2H, $J=4.7 \mathrm{~Hz}, \mathrm{OH}-6), 3.75-3.63$ (m, 4H, GlcNAc H-2, H6a), 3.53-3.15 (m, 8H, GlcNAc H-3, H-4, H-5, H-6b), $1.80,1.79\left(\mathrm{~s}, 6 \mathrm{H}, 2 \times \mathrm{NHCOCH}_{3}\right) ;{ }^{3} \mathrm{C} \mathrm{NMR}(75 \mathrm{MHz}$, DMSO- $\left.d_{6}\right): \delta 169.30 \quad(2 \mathrm{NHC}=O), 168.57 \quad(C=\mathrm{O})$, $159.05,159.01,152.45,151.51,151.46$ (5C), 135.80 (arom $\mathrm{CH}$ ), 130.33 (arom $\mathrm{CH}$ ), 129.20 (xanthene, $2 \mathrm{CH}$ ), 125.74 (1C), 124.81 (arom $\mathrm{CH}$ ), 123.98 (arom $\mathrm{CH}$ ), 113.77 (xanthene, 2CH), 112.31, 112.28 (2C), 103.27, 103.19 (xanthene, CH), $98.78(2 \mathrm{CH}, \mathrm{C}-1)$, 81.87 (xanthene, spiro C), 77.32, 73.91, 70.20 (each $2 \mathrm{CH}, \mathrm{C}-3, \mathrm{C}-4, \mathrm{C}-5), 60.71(2 \mathrm{CH}, \mathrm{C}-6), 55.32(2 \mathrm{CH}$, C-2), $23.04\left(2 \mathrm{CH}_{3}, \mathrm{NHCOCH}_{3}\right)$; HR FAB MS: Calcd for $\mathrm{C}_{36} \mathrm{H}_{38} \mathrm{~N}_{2} \mathrm{O}_{15} \mathrm{Cs}: \mathrm{m} / z$ 871.1327 $[\mathrm{M}+\mathrm{Cs}]^{+}$. Found: $m / z$ 871.1300. Anal. Calcd for $\mathrm{C}_{36} \mathrm{H}_{38} \mathrm{~N}_{2} \mathrm{O}_{15} \cdot \mathrm{H}_{2} \mathrm{O}: \mathrm{C}$, 57.14; H, 5.33; N, 3.70. Found: C, 56.89; H, 5.45; N, 3.70 .

\subsection{3'-[|2-(Acetylamino)-2-deoxy- $\beta$-D-glucopyran- osyl]oxy]-6'-hydroxyspiro[isobenzofuran-1(3H),9'-[9H]- xanthen]-3-one (6)}

O-Deacetylation of 4 (150 mg, $0.23 \mathrm{mmol})$ with aqueous $\mathrm{NH}_{3}$ was carried out as described for 4 . Purification of the crude material by reverse-phase HPLC offered $96 \mathrm{mg}$ of 5 as an orange colored powder $(0.18 \mathrm{mmol}$, 78\%): HPLC: $t_{\mathrm{R}}=11.3 \min \left(\mathrm{H}_{2} \mathrm{O} / \mathrm{CH}_{3} \mathrm{CN}(\mathrm{v} / \mathrm{v})\right.$ from 95:5 to $50: 50$ for $4 \mathrm{~min}, 50: 50$ to $27: 73$ for $11 \mathrm{~min}$, $27: 73$ to $20: 80$ for $1 \mathrm{~min}, 2 \mathrm{~mL} / \mathrm{min}) ;{ }^{1} \mathrm{H}$ NMR $\left(300 \mathrm{MHz}, \mathrm{DMSO}-d_{6}\right): \delta 8.01(\mathrm{~d}, 1 \mathrm{H}, J=7.2 \mathrm{~Hz}$, arom $\mathrm{H}), 7.81-7.69\left(\mathrm{~m}, 3 \mathrm{H}, 2 \times\right.$ arom $\left.\mathrm{H}, \mathrm{NHCOCH}{ }_{3}\right), 7.28$ (app. dd, $1 \mathrm{H}, J=7.5,3.6 \mathrm{~Hz}$ arom $\mathrm{H}$ ), 6.95 (app. s, $1 \mathrm{H}$, xanthene $\mathrm{H}), 6.71-6.64(\mathrm{~m}, 3 \mathrm{H}$, xanthene $\mathrm{H}), 6.58$ (app. s, 2H, xanthene $\mathrm{H}), 5.20-5.01(\mathrm{~m}, 2 \mathrm{H}, \mathrm{OH}), 5.07$ (d, $1 \mathrm{H}, J=8.7 \mathrm{~Hz}$, GlcNAc H-1), 4.67 (br s, 1H, OH), 3.80-3.16 (m, 6H, GlcNAc H-2, H-3, H-4, H-5, H-6a, H-6b), 1.79 (s, 3H, NHCOCH$H_{3}$; HR-ESIMS: Calcd for $\mathrm{C}_{28} \mathrm{H}_{25} \mathrm{~N}_{1} \mathrm{O}_{10} \mathrm{Na}: \mathrm{m} / z 558.1376[\mathrm{M}+\mathrm{Na}]^{+}$. Found: $\mathrm{m} / \mathrm{z} 558.1390$.

\subsection{Expression and purification of recombinant $O$-GlcNAcase and $v$ - $O$-GlcNAcase}

Details describing the cloning of pBAD/HisA human $O$ GlcNAcase (MGEA 5) and its splice variant (MGEA5 s) clones will be reported elsewhere. ${ }^{54}$ Cultures of TOP 10 cells containing $\mathrm{pBAD} / \mathrm{His}$ expression vector (Invitrogen) encoding the $\mathrm{His}_{6}$-tagged-O-GlcNAcase were grown overnight in Luria-Bertani (LB) broth (Digene) supplemented with ampicillin $(50 \mu \mathrm{g} / \mathrm{mL})$ at $37^{\circ} \mathrm{C}$ at $200 \mathrm{rpm}$. Induction of $O$-GlcNAcases was initiated by adding arabinose solution $(0.02 \%)$ when the $\mathrm{OD}_{600}$ of 
cultures reached at around 0.5 . The cultures were further grown for $4 \mathrm{~h}$ at $30^{\circ} \mathrm{C}$ at $200 \mathrm{rpm}$. The cells were harvested by centrifugation at $4000 \mathrm{~g}$ for $15 \mathrm{~min}$ in a Sorvall ${ }^{\circledR}$ RC 5C Plus (DuPont) centrifuge. The pellet was subjected to freeze-thaw and suspended in $1 / 50$ of the original volume in $0.1 \mathrm{mg} / \mathrm{mL}$ lysozyme, $20 \mathrm{mM}$ Tris- $\mathrm{HCl}, \mathrm{pH} 7.5,1 \mathrm{mM}$ DTT, $0.1 \%$ Triton X-100, an EDTA-free protease inhibitor cocktail tablet (1 tablet/ $10 \mathrm{~mL}$ ). The suspension was incubated at $\mathrm{rt}$ for $5 \mathrm{~min}$ and sonicated on ice $(4 \times 10 \mathrm{~s}$, setting 3 , Misonix Ultrasonic Processor). The supernatant obtained after centrifugation at 20,000 $\mathrm{g}$ for $15 \mathrm{~min}$ was stored in aliquots at $-80{ }^{\circ} \mathrm{C}$. Expressed $\mathrm{His}_{6}$-tagged $O$-GlcNAcase enzyme in the supernatant was purified on His-Trap HP column (Amersham Biosciences) according to the manufacture's protocol with minor variations. In this protocol, phosphate buffer ( $\mathrm{pH}$ 7.4) containing $40 \mathrm{mM}$ imidazole was used as a binding buffer and the column loaded with sample was washed successively with the binding buffer $(20 \mathrm{~mL})$ and phosphate buffer (pH 7.4) containing $60 \mathrm{mM}$ concentration of imidazole $(20 \mathrm{~mL})$. Elution with phosphate buffer ( $\mathrm{pH}$ 7.4) containing $300 \mathrm{mM}$ imidazole was performed at $1.0 \mathrm{~mL} / \mathrm{min}$ and the eluate was collected in $1 \mathrm{~mL}$ fractions. Fractions were assayed for protein by measuring absorbance at $280 \mathrm{~nm}$. Fractions containing protein were further assayed for $O$ GlcNAcase activity using the protocol described below in this section. Fractions showing enzyme activity were pooled and concentrated using a Centricon 100 microconcentrator (Amicon). Small amount of concentrated enzyme fraction was then reconstituted in $20 \mathrm{mM}$ Tris- $\mathrm{HCl}, \mathrm{pH}$ 7.5, $1 \mathrm{mM}$ DTT aqueous solution. Pierce BCA protein assay reagent was used to estimate protein concentration by using bovine serum albumin (BSA) as a standard protein. The purified shorter splice variant of $O$-GlcNAcase $(v$ - $O$-GlcNAcase) was prepared by the same protocol described above except using the phosphate buffer containing $10 \mathrm{mM}$ concentration of imidazole as a binding buffer and washing thoroughly with $20 \mathrm{~mL}$ of the binding buffer and eluting successively with $60,100,300 \mathrm{mM}$ imidazole phosphate buffer ( $\mathrm{pH}$ 7.4). Enzyme containing fractions were concentrated by using a Centricon 50 microconcentrator (Amicon) after fractions showing enzyme activity were pooled. Purity of the enzymes was confirmed by Ponceau S staining of the membrane (Sigma) and Western blot analysis using anti His-Tag antibody (Abcam) (see Fig. 1).

\section{7. $O$-GlcNAcase assay and enzyme kinetics with FDGIcNAc}

One international unit $(1 \mathrm{U})$ of $O$-GlcNAcase is defined as the amount that catalyzes the formation of $1.0 \mu \mathrm{mol}$ of FMGlcNAc and $1.0 \mu \mathrm{mol}$ of $N$-acetyl-D-glucosamine per minute at $\mathrm{pH} 6.5$ at $37^{\circ} \mathrm{C}$. Purified recombinant $O$ GlcNAcase $(0.17 \mu \mathrm{g}, 2 \mu \mathrm{L})$ was added to the solution containing the fluorogenic substrate, $\mathbf{5}$, of which concentration was varied $(10-300 \mu \mathrm{M})$ in $20 \mu \mathrm{L}$ of $0.5 \mathrm{M}$ citrate/phosphate buffer, $\mathrm{pH} 6.5$, in a final volume of $100 \mu \mathrm{L}$ at the start of the incubation at $37^{\circ} \mathrm{C}$. The assays were terminated by adding $900 \mu \mathrm{L}$ of $0.5 \mathrm{M}$ $\mathrm{Na}_{2} \mathrm{CO}_{3}$ solution after 3-5 min incubation. The assay solution $(200 \mu \mathrm{L})$ was transferred into a 96-well plate and fluorescence was measured at the excitation wavelength of $485 \mathrm{~nm}\left(\lambda_{\mathrm{ex}}=485 \mathrm{~nm}\right)$ and at the emission wavelength of $535 \mathrm{~nm}\left(\lambda_{\mathrm{em}}=535 \mathrm{~nm}\right)$ on the Wallac 1420 fluorometer (Perkin-Elmer ${ }^{\mathrm{TM}}$ Life Sciences). Assays were performed in triplicate.

\section{8. $v$-O-GlcNAcase assay and enzyme kinetics with FDGICNAc}

One unit of $v$-O-GlcNAcase is defined as the amount that catalyzes the formation of $1.0 \mu \mathrm{mol}$ of FMGlcNAc and $1.0 \mu \mathrm{mol}$ of $N$-acetyl-D-gluocosamine per minute at $\mathrm{pH} 6.5$ at $37^{\circ} \mathrm{C}$. The enzymatic reaction was initiated by adding $4 \mu \mathrm{L}$ of partially purified recombinant $v$-O GlcNAcase $(1.19 \mu \mathrm{g})$ to the solution containing the substrate, $\mathbf{5}$, which is varied $(0.2-20 \mathrm{mM})$ in $20 \mu \mathrm{L}$ of $0.5 \mathrm{M}$ citrate/phosphate buffer, $\mathrm{pH} 6.5$, in a final volume of $100 \mu \mathrm{L}$. The assays were terminated and quantitated as described for the $O$-GlcNAcase. Assays were performed in triplicate.

\section{9. $O$-GlcNAcase assay and enzyme kinetics with $p$ NP- $\beta$-GlcNAc}

One unit of $O$-GlcNAcase is defined as the amount that hydrolyzes $1.0 \mu \mathrm{mol}$ of $p \mathrm{NP}-\beta$-GlcNAc to $p$-nitrophenol and $N$-acetyl-D-gluocosamine per minute at $\mathrm{pH} 6.5$ at $37^{\circ} \mathrm{C}$. $p$ NP- $\beta$-GlcNAc $(14 \mathrm{mM})$ was prepared in $5 \%$ DMSO in water and used as a stock solution. Purified recombinant $O$-GlcNAcase $(0.18 \mu \mathrm{g})$ was added to increasing concentrations of $p$ NP- $\beta$-GlcNAc $(0.3-$ $8 \mathrm{mM})$ in $20 \mu \mathrm{L}$ of $0.5 \mathrm{M}$ citrate/phosphate buffer, $\mathrm{pH} 6.5$, in a final volume of $100 \mu \mathrm{L}$ at the start of the incubation at $37^{\circ} \mathrm{C}$. The assays were terminated by adding $900 \mu \mathrm{L}$ of $0.5 \mathrm{M} \mathrm{Na}_{2} \mathrm{CO}_{3}$ solution after $5 \mathrm{~min}$ incubation. The $p$-phenolate ion generated from the hydrolysis of $p$ NP- $\beta$-GlcNAc by the action of enzyme was spectrophotometrically measured at $400 \mathrm{~nm}$ on the UV 160U spectrophotometer (Shimadzu). Assays were performed in triplicate.

\subsection{Molar fluorescence coefficient of FMGIcNAc}

Standard dilutions made for calculating the molar fluorescence coefficient of FMGlcNAc on the Wallac 1420 fluorometer were as follows: $0.01,0.05,0.1,0.5,1.0$, $2.0,3.0,5.0,6.0,7.0,8.0,9.0,10$, and $12 \mu \mathrm{M}$ in $20 \mu \mathrm{L}$ of $0.5 \mathrm{M}$ citrate/phosphate buffer, $\mathrm{pH} 6.5,900 \mu \mathrm{L}$ of $0.5 \mathrm{M} \mathrm{Na}_{2} \mathrm{CO}_{3}$ solution in a total volume of $1 \mathrm{~mL}$. 
The assay solution $(200 \mu \mathrm{L})$ was transferred into a 96 well plate and fluorescence was measured at $\lambda_{\mathrm{ex}}=$ $485 \mathrm{~nm}$ and at $\lambda_{\mathrm{em}}=535 \mathrm{~nm}$ on the Wallac 1420 fluorometer with a continuous wave lamp set to 5028 in the stabilized energy mode and with the $4 \mathrm{~mm}$ diameter of circular aperture and $1 \mathrm{~s}$ of counting time. The plot of the concentrations of the standard versus their corresponding fluorescence intensities was constructed and the line-of-best-fit through the experimental points was obtained. The slope of this straight line is the molar fluorescence coefficient.

The calculated molar fluorescence constant of FMGlcNAc is 119,820 units/ $\mu \mathrm{M}$.

\subsection{Molar absorptivity of $p$ NP- $\beta$-GIcNAc}

$p$ NP- $\beta$-GlcNAc $(10 \mathrm{mM})$ was prepared in $5 \%$ DMSO in water and used as a stock solution. 3, 7, 10, 20, 30, 40, $50,65,80,100,110$, and $120 \mu \mathrm{M}$ of $p$ NP- $\beta$-GlcNAc were made in $20 \mu \mathrm{L}$ of $0.5 \mathrm{M}$ citrate/phosphate buffer, $\mathrm{pH} 6.5,900 \mu \mathrm{L}$ of $0.5 \mathrm{M} \mathrm{Na}_{2} \mathrm{CO}_{3}$ solution in a total volume of $1 \mathrm{~mL}$. Absorbance of para-phenolate ion in a series of dilution standards was measured at $400 \mathrm{~nm}$ at $25^{\circ} \mathrm{C}$ on the UV $160 \mathrm{U}$ spectrophotometer (Shimadzu). Assays were performed in triplicate. The plot of the concentrations of the standard versus their corresponding absorbance was constructed and the line-of-best-fit through the experimental points was obtained. From the slope of this straight line, calculated molar absorptivity of $p$ NP- $\beta$-GlcNAc is $18.8 \mathrm{mM} \mathrm{cm}^{-1}$.

\subsection{Substrate specificity}

Either $2 \mu \mathrm{L}$ of purified recombinant $O$-GlcNAcase $(0.17 \mu \mathrm{g})$ or $4 \mu \mathrm{L}$ of partially purified recombinant $v$-O-GlcNAcase $(1.19 \mu \mathrm{g})$ was added to the solution containing $30 \mu \mathrm{M}$ of FDGalNAc (Marker Gene Technologies, Inc.) in $20 \mu \mathrm{L}$ of $0.5 \mathrm{M}$ citrate/phosphate, $\mathrm{pH} 6.5$, in a final volume of $100 \mu \mathrm{L}$ and incubated at $37^{\circ} \mathrm{C}$ for $30 \mathrm{~min}$. The assays were terminated by adding $900 \mu \mathrm{L}$ of $0.5 \mathrm{M} \mathrm{Na}_{2} \mathrm{CO}_{3}$ solution. The assay solution $(200 \mu \mathrm{L})$ was transferred into a 96-well plate and fluorescence was measured at $\lambda_{\mathrm{ex}}=485 \mathrm{~nm}$ and at $\lambda_{\mathrm{em}}=$ $535 \mathrm{~nm}$ on the Wallac 1420 fluorometer.

\subsection{Preparation of HT-29 and HeLa cell extracts, enzyme activity assay, and Western blotting}

The suspension of $10 \mathrm{~mL}$ culture of PUGNAC treated HT-29 cells was centrifuged at $2500 \mathrm{~g}$ for $10 \mathrm{~min}$. The pellet was suspended in $0.3 \mathrm{~mL}$ of lysis buffer containing $20 \mathrm{mM}$ Tris- $\mathrm{HCl}, \mathrm{pH} 8.0,1 \mathrm{mM}$ DTT, $0.1 \%$ Triton $\mathrm{X}-100$, an EDTA-free protease inhibitor cocktail (1 tablet $/ 10 \mathrm{~mL}$ ). The suspension was incubated at $\mathrm{rt}$ for $5 \mathrm{~min}$ and sonicated on ice $(4 \times 10 \mathrm{~s}$, setting 3 , Misonix Ultrasonic Processor). The supernatant obtained after centri- fugation at 20,000 $\mathrm{g}$ for $15 \mathrm{~min}$ was stored in aliquots at $-80^{\circ} \mathrm{C}$. PUGNAC treated HeLa cell extracts were prepared using MPER protein extraction reagent (Pierce) according to the manufacturer's protocol from a $10 \mathrm{~mL}$ suspension of cultured cells. Protein $(20 \mu \mathrm{g})$ was incubated with 0 (control), $7 \mu \mathrm{g}, 5 \mu \mathrm{g}$ of $O$-GlcNAcase, and $5 \mu \mathrm{g}$ of $v$-O-GlcNAcase in $0.05 \mathrm{M}$ citrate/phosphate buffer, $\mathrm{pH} 6.5$, in a final volume of $22.5 \mu \mathrm{L}$ at $37^{\circ} \mathrm{C}$ for $3 \mathrm{~h}$. Reactions were stopped by adding $7.5 \mu \mathrm{L}$ of $\mathrm{Nu}-$ PAGE ${ }^{\circledR}$ LDS sample buffer $(4 \times)$. Samples were loaded onto a $10 \%$ NuPAGE pre-cast gel and proteins were separated by electrophoresis and then transferred to a nitrocellulose membrane for immunoblotting. The blot was probed with $O$-GlcNAc specific antibody RL2 (mouse IgG1, Affinity Bioreagents, Inc.) at 1:1000 dilution. Peroxidase-conjugated goat anti-mouse IgG (Jackson Immunoresearch Laboratories, Inc.) was used as the secondary antibody. The blot was visualized with enhanced SuperSignal ${ }^{\circledR}$ West Pico Chemiluminescent Substrate (Pierce) (see Fig. 6).

\section{Acknowledgments}

This research was financially supported by National Institute of Health Grants (VFJA009594). We thank Mr. Victor Livengood who is an operator of the mass spectrometers in the NIDDK, NIH for obtaining the mass spectral data and allowing us to use LC-ESI instrument for monitoring the time-course of the enzyme reaction.

\section{References}

1. Jackson, S. P.; Tjian, R. Cell 1988, 55, 125-133.

2. Jackson, S. P.; Tjian, R. Proc. Natl. Acad. Sci. U.S.A. 1989, 86, 1781-1785.

3. Kelly, W. G.; Dahmus, M. E.; Hart, G. W. J. Biol. Chem. 1993, 268, 10416-10424.

4. Holt, G. W.; Haltiwanger, R. S.; Torres, C.-R.; Hart, G. W. J. Biol. Chem. 1987, 262, 14847-14850.

5. Dong, L.-Y.; Xu, Z.-S.; Chevrier, M. R.; Cotter, R. J.; Cleveland, D. W.; Hart, G. W. J. Biol. Chem. 1993, 268, 16679-16687.

6. Chou, T.-Y.; Dang, C. V.; Hart, G. W. Proc. Natl. Acad. Sci. U.S.A. 1995, 92, 4417-4421.

7. Lubas, W. A.; Hanover, J. A. J. Biol. Chem. 2000, 275, 10983-10988.

8. Meikrantz, W.; Smith, D. M.; Sladicka, M. M.; Schlegel, R. A. J. Cell Sci. 1991, 98, 303-307.

9. Walgren, J. L.; Vincent, T. S.; Schey, K. L.; Buse, M. G. Am. J. Physiol.: Endocrinol. Metab. 2003, 284, E424E434.

10. Roquemore, E. P.; Chevrier, M. R.; Cotter, R. J.; Hart, G. W. Biochemistry 1996, 35, 3578-3586.

11. Lefebvre, T.; Cieniewsi, C.; Lemoine, J.; Guerardel, Y.; Leroy, Y.; Zanetta, J. P.; Michalski, J. C. Biochem. J. 2001, 360, 179-188. 
12. Kearse, K. P.; Hart, G. W. Proc. Natl. Acad. Sci. U.S.A. 1991, 88, 1701-1705.

13. Chou, C. F.; Smith, A. J.; Omary, M. B. J. Biol. Chem. 1992, 267, 3901-3906.

14. Ku, N. O.; Omary, M. B. Exp. Cell Res. 1994, 211, 24 35.

15. Favreau, C.; Worman, H. J.; Wozniak, R. W.; Frappier, T.; Courvalin, J. C. Biochemistry 1996, 35, 8035-8044.

16. Cheng, X.; Cole, R. N.; Zaia, J.; Hart, G. W. Biochemistry 2000, 39, 11609-11620.

17. Comer, F. I.; Hart, G. W. Biochemistry 2001, 40, 78457852.

18. Chou, T. Y.; Hart, G. W.; Dang, C. V. J. Biol. Chem. 1995, 270, 18961-18965.

19. McClain, D. A.; Lubas, W. A.; Cooksey, R. C.; Hazel, M.; Parker, G. J.; Love, D. C.; Hanover, J. A. Proc. Natl. Acad. Sci. U.S.A. 2002, 99, 10695-10699.

20. Shaw, P.; Freeman, J.; Bovey, R.; Iggo, R. Oncogene 1996, 12, 921-930.

21. Arnold, C. S.; Johnson, G. V.; Cole, R. N.; Dong, D. L.; Lee, M.; Hart, G. W. J. Biol. Chem. 1996, 271, 2874128744.

22. Vosseller, K.; Wells, L.; Lane, M. D.; Hart, G. W. Proc. Natl. Acad. Sci. U.S.A. 2002, 99, 5313-5318.

23. Haltiwanger, R. S.; Blomberg, M. A.; Hart, G. W. J. Biol. Chem. 1992, 267, 9005-9013.

24. Hartweck, L. M.; Scott, C. L.; Olszewski, N. E. Genetics 2002, 161, 1279-1291.

25. Lubas, W. A.; Frank, D. W.; Krause, M.; Hanover, J. A. J. Biol. Chem. 1997, 272, 9316-9324.

26. Kreppel, L. K.; Hart, G. W. J. Biol. Chem. 1999, 274, 32015-32022.

27. Gao, Y.; Wells, L.; Comer, F. I.; Parker, G. J.; Hart, G. W. J. Biol. Chem. 2001, 276, 9838-9845.

28. Wrabl, J. O.; Grishin, N. V. J. Mol. Biol. 2001, 314, 365374.

29. Dong, D. L.; Hart, G. W. J. Biol. Chem. 1994, 269, 1932119330.

30. Jinek, M.; Rehwinkel, J.; Lazarus, B. D.; Izaurralde, E.; Hanover, J. A.; Conti, E. Nat. Struct. Mol. Biol. 2004, 11, 1001-1007.

31. Braidman, I.; Carroll, M.; Dance, N.; Robinson, D.; Poenaru, L.; Weber, A.; Dreyfus, J. C.; Overdijk, B.; Hooghwinkel, G. J. FEBS Lett. 1974, 41, 181-184.

32. Overdijk, B.; Van der Kroef, W. M.; Van Steijn, G. J.; Lisman, J. J. Biochim. Biophys. Acta 1981, 659, 255-266.

33. Heckel, D.; Comtesse, N.; Brass, N.; Blin, N.; Zang, K. D.; Meese, E. Hum. Mol. Genet. 1998, 7, 1859-1872.
34. Comtesse, N.; Maldener, E.; Meese, E. Biochem. Biophys. Res. Commun. 2001, 283, 634-640.

35. Schultz, J.; Pils, B. FEBS Lett. 2002, 529, 179-182.

36. Toleman, C.; Paterson, A. J.; Whisenhunt, T. R.; Kudlow, J. E. J. Biol. Chem. 2004, 279, 53665-53673.

37. Macauley, M. S.; Whitworth, G. E.; Debowski, A.; Chin, D.; Vocadlo, D. J. J. Biol. Chem. 2005, 280, 25313-25322.

38. Hanover, J. A. FASEB J. 2001, 15, 1865-1876.

39. Rigden, D. J.; Jedrzejas, M. J.; de Mello, L. V. FEBS Lett. 2003, 544, 103-111.

40. Wells, L.; Gao, Y.; Mahoney, J. A.; Voseller, K.; Chen, C.; Rosen, A.; Hart, G. W. J. Biol. Chem. 2002, 277, 17551761.

41. Glasgow, L. R.; Paulson, J. A.; Hill, R. L. J. Biol. Chem. 1977, 252, 8615-8623.

42. Yegorov, A. M.; Markaryan, A. N.; Vozniy, Y. V.; Cherednikova, T. V.; Demcheva, M. V.; Berezin, I. V. Anal. Lett. 1988, 21, 193-209.

43. Rakhmanova, V. A.; MacNonald, R. C. Anal. Biochem. 1998, 257, 234-237.

44. MacGregor, G. R.; Nolan, G. P.; Fiering, S.; Roederer, M.; Herzenberg, L. A. In Gene Expression in Vivo; Murray, E. J., Walker, J. M., Eds.; Humana Press: Clifton, NJ, 1990; pp 217-236.

45. Young, D. C.; Kingsley, S. D.; Ryan, K. A.; Dutko, F. J. Anal. Biochem. 1993, 215, 24-30.

46. Berg, M.; Undisz, K.; Thiericke, R.; Moore, T.; Posten, C. J. Biomol. Screen. 2000, 5, 71-76.

47. Kasai, K.; Uchida, R.; Yamaji, N. Chem. Pharm. Bull. 1993, 41, 314-318.

48. Arias, E. B.; Kim, J.; Cartee, G. D. Diabetes 2004, 53, 921-930.

49. Park, S. Y.; Ryu, J.; Lee, W. Exp. Mol. Med. 2005, 37, 220-229.

50. Arias, E. B.; Cartee, G. D. Acta Physiol. Scand. 2005, 183, 281-289.

51. Perreira, M.; Kim, E. J.; Thomas, C. J.; Hanover, J. A. Bioorg. Med. Chem. 2006, 14, 837-846.

52. Lehman, D. M.; Fu, D. J.; Freeman, A. B.; Hunt, K. J.; Leach, R. J.; Johnson-Pais, T.; Hamlington, J.; Dyer, T. D.; Arya, R.; Abboud, H.; Goring, H. H.; Duggirala, R.; Blangero, J.; Konrad, R. J.; Stern, M. P. Diabetes 2005 , $54,1214-1221$

53. Horton, D. In Methods in Carbohydrate Chemistry; Whistler, R. L., BeMiller, J. N., Eds.; Academic: New York, 1972; pp 282-285.

54. Kang, D. O.; Lee, G.; Kim, E. J.; Hanover, J. A., in preparation. 